\title{
Sustainable Jet Fuel Production: Using Pumpkin Seed Oil
}

\author{
Sinem GÜRKAN AYDIN ${ }^{1}$, Arzu ÖZGEN ${ }^{2}$ \\ ${ }^{1}$ Istanbul Gelisim University, Vocational School of Health Services, Opticianry, İstanbul, Turkey \\ ${ }^{2}$ Istanbul Gelisim University, Vocational School of Health Services, Medical Laboratory Techniques, \\ Istanbul, Turkey
}

\begin{abstract}
Biofuels are fuels of biological origin, and they are among the prominent energy sources from renewable energy sources in recent years. Unlike fuels such as petroleum derivatives, coal, natural gas, biofuels are renewable and sustainable energy sources. Biofuels can be obtained by thermochemical or biochemical methods from agricultural and forestry products, animal and vegetable residues and wastes, organic origin domestic, industrial and urban wastes. Global warming caused by greenhouse gas effect is today shown as the most important common environmental problem in the world. The most important advantage of using biofuels in environmental terms is that there will be a reduction of greenhouse gas impact and acid rain.

In this study, it is aimed to produce and characterize jet fuel by converting from pumpkin (Cucurbita pepo) seed oil, which is a sustainable bio energy source, into biofuel, by transesterification method. It has an important place in matters such as environment, sustainability, and reduction of carbon emissions. Biojet fuel produced using pumpkin seed oil, which is a sustainable resource, is a candidate product for development and commercialization.
\end{abstract}

Keywords - Jet Fuel, Biojet, Pumpkin seed, Sustainable energy, Ecology.

DOI: 10.18421/TEM102-49

https://doi.org/10.18421/TEM102-49

Corresponding author: Sinem GÜRKAN AYDIN, istanbul Gelisim University, Vocational School of Health Services, Opticianry, istanbul Turkey.

Email: sgurkan@gelisim.edu.tr

Received: 09 March 2021.

Revised: 22 April 2021.

Accepted: 28 April 2021.

Published: 27 May 2021.

(cc) BY-NC-ND@ 2021 Sinem GÜRKAN AYDIN \& Arzu ÖZGEN; published by UIKTEN. This work is licensed under the Creative Commons Attribution-NonCommercialNoDerivs 4.0 License.

The article is published with Open Access at www.temjournal.com

\section{Introduction}

Energy plays an important role in the development of all countries and in our daily life [1]. Energy is the most important factor that provides progress in the development of countries and supports the increase of living standards economically and socially. In addition to the increase in the world population, changes and developments in the industry cause the need for energy [1], [2].

The world consumption of primary energy sources increased by $2.5 \%$ in 2012 compared to the previous year. This increase has become more evident in recent years. Today, the share of fossil fuels in energy consumption continues [2], [3]. According to the information obtained in 2016; petroleum is the highest amount with $33.3 \%$ of energy consumption worldwide. Worldwide, $28.1 \%$ of energy consumption is coal, $24.1 \%$ is natural gas, $6.9 \%$ is hydraulic energy, $4.5 \%$ is nuclear energy and finally 3.2 are renewable energy sources. [4]

Approximately $95 \%$ of transportation energy is obtained from petroleum-derived fuels. In addition, almost $60 \%$ of the crude oil produced is used in the production of transportation fuels [5], [6], [7], [8]. Worldwide, the demand for fuels for transport is increasing. $1 \%$ annual growth is expected in this increase [9]. The increase in the population and the increase in the demand for transportation are also effective. Biofuels can be preferred to traditional fuels produced from crude oil, considering factors such as greenhouse gas emissions, environmental impact, energy security, and prevention of air pollution. Of course, although this transition is not easy, it has some difficulties. Based on the coming years, it is thought that it will remain below $10 \%$ until 2040 [5], [7].

The need for jet fuels has been increasing over the years. The need, which is 320 million tons per year today, is projected to be 430 million tons by 2040 . [10]. Jet fuel has made up approximately $20 \%$ of the production of the US oil refinery for the past two decades [11]. Jet fuels are such a huge sector in the consumption of fossil fuels that they have a market 
value of 207 billion dollars in 2012 alone $(33 \%$ of operating costs are calculated as $\$ 110.0$ / barrel of Brent oil) [12]. Jet fuels continue to rise steadily. As an example, the United States can be given with 1670 thousand barrels of jet fuel consumption in a day [13].

Sustainable aviation fuels are a good solution for decarbonization, although they pose difficulties in supply and demand. In fact, sustainable aviation fuels produce the same amount of $\mathrm{CO} 2$ emissions as conventional jet fuels. The reason for the improvement is that the manufacturing process absorbs $\mathrm{CO} 2$ and leads to a 70 to 100 percent reduction in $\mathrm{CO} 2$ emissions on a life-cycle basis, in other words it is less carbon intensive. The use of advanced biofuels has the potential to produce solutions in a short time. Some airlines use these fuels in their daily operations. The fuels used are fuels whose feasibility has been proven by technical analysis obtained from vegetable or waste oils.

Today, although biofuels play an important role in sustainable development, they are also in demand alternative fuels. Economically, it is now the basis of the transition to a bio-based economy. With the development of the aviation industry worldwide, interest in biofuels has also increased. Large international organizations International Air Transport Association (IATA) and the International Civil Aviation Organization (ICAO) have approached this issue sensitively and have committed to reducing emissions and stopping the growth of carbon emissions [14], [15]. Studies in the literature have examined the greenhouse gas emissions (GHG) of aviation biofuels produced by different techniques [16], [17]. This issue is very important in terms of the sustainability of our living space and energy.

With all these investigations, concerns about decreasing fossil fuel reserves and increasing carbon dioxide levels in the atmosphere have increased. This has fueled the advances in alternative jet fuel research [18]. In the short term, promising approaches may not work. Sugar and [19] other synthesis pathways [20], [21] bio Fischer Tropsch synthesis-synthesis gas, catalytic conversion to produce bio-jet fuels from various biomass raw materials Animal and vegetable oils have been developed including hydrotreating. Among the fuels that may be alternative to petroleum-derived fuels used in the aviation industry, vegetable oil-based fuels such as camelina, jatropha and algae oil come to the fore.

In this study, it is aimed to produce and characterize jet fuel by converting from pumpkin (Cucurbita pepo) seed oil, which is a sustainable bio energy source, into biofuel, by transesterification method.

\section{Materials and Methods}

In our study, one-step basic reaction method, which is generally preferred for refined and crude vegetable oils, was used for transesterification. 100 $\mathrm{ml}$ of methanol and $5 \mathrm{~g}$ of $\mathrm{NaOH}$ were used for 500 $\mathrm{ml}$ of pumpkin seed oil. $100 \mathrm{ml}$ of methanol and $5 \mathrm{~g}$ of $\mathrm{NaOH}$ were mixed in a magnetic stirrer heater at $40^{\circ} \mathrm{C}$ for 30 minutes. The sodium methoxide (CH3ONa) obtained as a result of this process was kept in the oven at $50{ }^{\circ} \mathrm{C}$ in order to maintain the temperature.

Then, pumpkin seed oil was heated up to $60^{\circ} \mathrm{C}$ using a magnetic heater and added to $\mathrm{CH} 3 \mathrm{ON}$. The mixture was stirred at approximately $55-60{ }^{\circ} \mathrm{C}$ for 2 hours. The mixture was allowed to stand at room temperature for 80 hours to complete the transesterification process. At the end of this process, a two-phase mixture consisting of biodiesel-glycerin was obtained [22].

The supernatant containing fatty acid was carefully taken with a pipette and transferred to a clean tube. The fatty acid-glycerin border part was centrifuged at $600 \mathrm{rpm}$ for 5 minutes and the fatty acid part was recovered.

In order to remove soap, glycerine and mono-di-tri glycerides that may be present in biodiesel, washing process was carried out using pure water. Washing process was carried out 5 times by spraying on biodiesel at the ratio of pure water (1: 1) heated up to $100^{\circ}$ C. After the last wash, it was waited for approximately 10 hours and the washing water was separated from the biodiesel and settled to the bottom. The biodiesel in the upper phase was carefully removed and dried in the oven at $110-120^{\circ}$ $\mathrm{C}$ to completely remove the remaining pure water and alcohol. Jet fuel was obtained by adding kerosene and octane increasing chemicals at a rate of 25 percent to the dried fuel. Optimized structure, geometric properties and energies of fuel additives have been studied previously. Additives have been selected based on scientific data [23]. The fuel obtained is 50 percent vegetable-based jet fuel. The sample was sent to TUBITAK in order to determine the properties of the biodiesel obtained.

\section{Result and Discussion}

Renewable aviation fuels are generally produced with triglycerides, lignocelulosides and syntetis gas, and biofuels can be obtained from plants, animal fats and biomass. Biofuels reduce $\mathrm{CO}_{2}$ emissions, especially when produced from plant and organic wastes. This is because plants use $\mathrm{CO}_{2}$ as they grow, and they also reduce their dependence on oil [24]. In addition to these, bacteria, yeast and algae have the capacity to produce fuel molecules, and they are used in biofuel production. Product diversity can be improved by changing existing methods or through engineering applications and synthetic means [25]. 
Table 1. Comparison of the bio jet sample results produced according to the standards

\begin{tabular}{|c|c|c|c|c|c|}
\hline Specification & $\begin{array}{c}\text { Bio jet sample } \\
\text { results produced }\end{array}$ & $\underset{[27]}{\operatorname{ASTMD} 1655}$ & $\begin{array}{c}\text { Joint Check } \\
\text { List }\end{array}$ & MIL-T-5624 & MIL-T-5624 \\
\hline Grade & & Jet A/A-1 & Jet A-1 & JP-5 & JP-4 \\
\hline \multicolumn{6}{|l|}{ Property } \\
\hline Aromatics, vol. \% Max. & 33,6 & 25 & 22 & 25.0 & 25.0 \\
\hline Sulfur, mass \% Max. & 0,0007 & 0.3 & 0.30 & 0.40 & 0.40 \\
\hline \multicolumn{6}{|l|}{ Distillation, ${ }^{\circ} \mathrm{C}\left({ }^{\circ} \mathrm{F}\right)$} \\
\hline $10 \% \operatorname{Rec} \operatorname{Max}$ & 205 & 205 & 205 & 206 & \\
\hline $50 \% \operatorname{Rec}$ & 206 & & & & $125 \max$ \\
\hline $90 \% \operatorname{Rec}$ & 335,6 & & & & \\
\hline Final BP Max & & 300 & 300 & 300 & 270 \\
\hline Flash point, ${ }^{\circ} \mathrm{C}\left({ }^{\circ} \mathrm{F}\right) \mathrm{Min}$. & 39 & 38 & 40 & 60 & \\
\hline Density, $\mathrm{kg} / \mathrm{m}^{3}$ & 819,5 & $775-840$ & $775-840$ & $788-845$ & \\
\hline Freezing point, ${ }^{\circ} \mathrm{C}\left({ }^{\circ} \mathrm{F}\right) \mathrm{Max}$ & -45 & -40 & -47 & -46 & -58 \\
\hline Viscosity@-20C, cs Max & 8,1 & 8 & 8.0 & 8.5 & \\
\hline Specific energy, MJ/kg Min. & 42,8 & 42.8 & 42.8 & 42.6 & 42.8 \\
\hline
\end{tabular}

Although the selection of organisms takes a large place in order to increase productivity in such applications, genetic optimization is required. The development of cellulosic bioethanol is one of the best commercial successes.

Another production method of sustainable fuels is HEFA technology. Hefa technology is obtained by hydro-processing of vegetable oils and animal fats. Approximately 1.2 tons of vegetable oil is required for 1 ton of HEFA fuel.

One of the main advantages of this technology pathway is to integrate this process into an oil refinery (with an additional step) and avoid the need to develop a special production facility. The HEFA production route has been proven and already certified for mix ratios of up to $50 \%$, and existing investments in the infrastructure show that the route has the scope of being economically viable in the near future [26].

It cannot be used as pure vegetable oil in aircraft equipped with gas turbines. For this reason, it is necessary to bring its combustion-related properties closer to diesel. While the fuel regulation to be made in this way aims to reduce the viscosity, it will eliminate the problems related to atomization. Four techniques can be used for this. These techniques can be listed as heating, dilution / mixing, micro emulsion and trans-esterification.

The jet fuel sample produced with pumpkin seed oil was analyzed in the laboratory in accordance with the standards. In the analysis results, it was concluded that it is compatible with the features determined by international authorities. The properties of the fuel produced in our study and its comparison with the standards are given in Table 1.
In addition, motor octane number analysis was made, and the value of 114 was found as a result of the analysis. This value shows that it is very suitable for use. The lost and residual amounts have been determined, respectively, $05 \mathrm{ml}$ and $0.8 \mathrm{ml}$. In all evaluations, it has been concluded that the biojet fuel produced complies with the standards and can be developed and produced.

\section{Conclusion}

Air transport is a vital feature of our modern, globalized world and connects people and businesses across continents. The benefits of air travel are obvious, but there are also aspects of it that have an environmental impact. Traditionally, environmental issues involving aviation have focused on noise and air pollution affecting the environment surrounding airports. Recently, the issue of global climate change, which has come to the fore, has focused attention on the CO2 emission volumes of aircraft. When greenhouse gases produced from fuel burned in flights are released into the atmosphere, they have a negative impact on global climate change. Aviation is likely to need around 450-500 million tons of sustainable aviation fuels per year by 2050 . This can be achieved with strong sustainability criteria.

Jet fuels produced using renewable bio-based resources are important for the aviation industry. Most importantly, it reduces dependence on fossil fuels. It is one of the important breakthroughs as it will contribute to the targets of reducing emissions against global problems. 
There is a wide variety of raw materials for bio-jet fuel production. The main challenges to commercialization of jet fuel are raw material availability, economy and sustainability.

Given the large-scale use of bio-jet fuels, significant greenhouse gas emission reduction potential can be achieved in the future by using existing biomass feedstock. For this reason, our work has an important place in matters such as environment, sustainability, and reduction of carbon emissions. As a result, biojet fuel produced using pumpkin seed oil, which is a sustainable resource, is a candidate product for development and commercialization.

\section{References}

[1]. Koç, E., \& Şenel, M. C. (2013). Dünyada ve Türkiye'de enerji durumu-genel değerlendirme. Mühendis ve Makina, 54(639), 32-44.

[2]. Yağl1, H., Koç, Y., Koç, A., Görgülü, A., \& Tandiroğlu, A. (2016). Parametric optimization and exergetic analysis comparison of subcritical and supercritical organic Rankine cycle (ORC) for biogas fuelled combined heat and power (CHP) engine exhaust gas waste heat. Energy, 111, 923-932.

[3]. Yagli, H., Koc, A., Karakus, C., \& Koc, Y. (2016). Comparison of toluene and cyclohexane as a working fluid of an organic Rankine cycle used for reheat furnace waste heat recovery. International Journal of Exergy, 19(3), 420-438.

[4]. Ali, K. O. Ç., Yağli, H., Yıldız, K. O. Ç., \& Uğurlu, İ. (2018). dünyada ve türkiye'de enerji görünümünün genel değerlendirilmesi. Mühendis ve Makina, 59(692), 86-114.

[5]. Smith, M. N. (2016). The number of cars will double worldwide by 2040. Business Insider. Retreived from: https://www.businessinsider.com/global-transportuse-will-double-by-2040-as-china-and-india-gdpballoon [accessed: 25 February 2021].

[6]. Colton, W. M. (2011). The Outlook for Energy: A View to 2040. Exxon Mobil Corporation.

[7]. Gadonneix, P., Sambo, A., Tie'nan, L., Choudhury, A. R., Teyssen, J., Lleras, J. A. V., ... \& Frei, C. (2011). Global Transport Scenarios 2050. World Energy Council.

[8]. Nilsson, M. (2016). 10 Organization of the Petroleum Exporting Countries (OPEC). International Organizations and The Rise of ISIL: Global Responses to Human Security Threats, 169.

[9]. Conti, J., Holtberg, P., Diefenderfer, J., LaRose, A., Turnure, J. T., \& Westfall, L. (2016). International energy outlook 2016 with projections to 2040 (No. DOE/EIA-0484 (2016)). USDOE Energy Information Administration (EIA), Washington, DC (United States). Office of Energy Analysis.

[10]. Wagner, H. L. (2009). The Organization of the Petroleum Exporting Countries. Infobase Publishing.

[11]. Davidson, C., Newes, E., Schwab, A., \& Vimmerstedt, L. (2014). Overview of Aviation Fuel Markets for Biofuels Stakeholders (No. NREL/TP6A20-60254). National Renewable Energy Lab.(NREL), Golden, CO (United States).
[12]. IATA, I. (2013). International Air Transport Association. Annual Review. Retrieved from: https:/www.iata.org/contentassets/c81222d96c9a4e0b b4ff6ced0126f0bb/iata-annual-review-2013-en.pdf [accessed 05 January 2021].

[13]. Census Bureau. (2009). Statistical abstract of the United States. Statistical Abstract of the Un.

[14]. Turner, B. (2010). International Air Transport Association (IATA). In The Statesman's Yearbook (pp. 45-46). Palgrave Macmillan, London.

[15]. Abeyratne, R. (2017). Outcome of the 39th Session of the International Civil Aviation Organization Assembly. Air and Space Law, 42(1).

[16]. Bailis, R. E., \& Baka, J. E. (2010). Greenhouse gas emissions and land use change from Jatropha curcasbased jet fuel in Brazil. Environmental science \& technology, 44(22), 8684-8691.

[17]. Crossin, E. (2013). Mallee aviation biofuels life cycle assessment. Melbourne: Future Farm Industries $C R C$.

[18]. Dudley, B. (2018). BP statistical review of world energy. BP Statistical Review, London, UK, accessed Aug, 6(2018), 00116.

[19]. Salvi, B. L., Subramanian, K. A., \& Panwar, N. L. (2013). Alternative fuels for transportation vehicles: a technical review. Renewable and Sustainable Energy Reviews, 25, 404-419.

[20]. Mahmudul, H. M., Hagos, F. Y., Mamat, R., Adam, A. A., Ishak, W. F. W., \& Alenezi, R. (2017). Production, characterization and performance of biodiesel as an alternative fuel in diesel engines-A review. Renewable and Sustainable Energy Reviews, 72, 497-509.

[21]. Australian Energy Council (2016). Solar report. Retrieved from:

https:/www.energycouncil.com.au/media/6016/201606-10_australian-energy-council-solar-report_sep2016.pdf [accessed 27 January 2021].

[22]. Leung, D. Y., Wu, X., \& Leung, M. K. H. (2010). A review on biodiesel production using catalyzed transesterification. Applied energy, 87(4), 1083-1095.

[23]. Aydin, S. G., Polat, O., Ozgen, A., \& Turali, E. (2020). Calculated Optimized Structure and Geometric Analysis of Oxygenated Fuel Additives: Alcohols and Ethers. Engineering, Technology \& Applied Science Research, 10(3), 5632-5636.

[24]. Naik, S. N., Goud, V. V., Rout, P. K., \& Dalai, A. K. (2010). Production of first and second generation biofuels: a comprehensive review. Renewable and Sustainable Energy Reviews, 14(2), 578-597.

[25]. McEwen, J. T., \& Atsumi, S. (2012). Alternative biofuel production in non-natural hosts. Current Opinion in Biotechnology, 23(5), 744-750.

[26]. IATA, I. (2015). Sustainable Aviation Fuel Roadmap. International Air Transport Association, Montreal and Geneva.

[27]. Wei, H., Liu, W., Chen, X., Yang, Q., Li, J., \& Chen, H. (2019). Renewable bio-jet fuel production for aviation: A review. Fuel, 254, 115599. 